\title{
INTERTIDAL POLYCHAETES AS INDICATORS OF POLLUTION RESULTING FROM ANTHROPOGENIC ACTIVITIES ALONG THE OKPOKA CREEK, UPPER BONNY ESTUARY, NIGERIA
}

\section{Tamunotonye Kalio*, Miebaka Moslen and Ikem Kris Eloka Ekweozor}

\author{
Department of Animal and Environmental Biology Rivers State, University, Port harcourt, \\ Nigeria \\ *Corresponding Author Email: kalio_tamunotonye@yahoo.com
}

\begin{abstract}
Cite this article:
Tamunotonye K., Miebaka M., Ikem K.E.E. (2021), Intertidal Polychaetes as Indicators of Pollution Resulting from Anthropogenic Activities along the Okpoka Creek, Upper Bonny Estuary, Nigeria. African Journal of Environment and Natural Science Research 4(2), 71-82. DOI: 10.52589/AJENSR6IMJLFPQ.
\end{abstract}

\section{Manuscript History}

Received: 23 April 2021

Accepted: 17 May 2021

Published: 21 May 2021

Copyright $\odot 2020$ The Author(s). This is an Open Access article distributed under the terms of Creative Commons AttributionNonCommercial-NoDerivatives 4.0 International (CC BY-NC-ND 4.0 ), which permits anyone to share, use, reproduce and redistribute in any medium, provided the original author and source are credited.
ABSTRACT: The Okpoka river and the Amadi creek are tributaries of the upper bonny estuary. The study is aimed at identifying the intertidal polychaete species and their abundance in these areas, and using them as indicators of pollution. Three stations were sampled for 6 months on a monthly basis at Marine Base, Abuloma and Kalio-Ama. Results gotten from Water samples collected from intertidal pools are as follows; Biochemical Oxygen Demand(BOD) (3.31-4.0)mg/l, Dissolved Oxygen(DO) (6.40-6.44) mg/l, Conductivity (22.69-25.89)ms/cm, Total Dissolved Solids(TDS) (11.34-12.96)PPT, Salinity (13.65-15.74)PPT, pH (6.58-6.86), Turbidity (45.41-75.11)NTU, Temperature (28.30$31.82)^{\circ} \mathrm{C}$, Nitrate $\left(\mathrm{NO}_{3}\right) \quad(2.11-4.10) \mathrm{mg} / \mathrm{l}, \quad$ Phosphate $\left(\mathrm{PO}_{4}\right) \quad(0.82-$ 1.10)mg/l, Sulphate( $\mathrm{SO}_{4}$,) (7.51-15.38)mg/l and Total Petroleum Hydrocarbon(TPH) (0.03-0.13)mg/l. The values of $\mathrm{NO}_{3}, \mathrm{pH}$, Conductivity, TDS, Salinity showed significance in location and time. $\mathrm{PO}_{4}$ was significantly different between locations ( $p<0.05$ ). $\mathrm{BOD}, \mathrm{SO}_{4}$, TPH and DO showed significance in time while Turbidity and Temperature showed no significance. Results gotten from Analysis done for sediment nutrient parameters such as $\mathrm{NO}_{3}(15.50-26.40) \mathrm{mg} / \mathrm{l}$ and $\mathrm{PO}_{4}(13.32-15.90) \mathrm{mg} / \mathrm{l}$ showed significant variations in location and time, TPH(21.93-34.71) $\mathrm{mg} / \mathrm{l}$ showed significant variations in location and $\mathrm{SO}_{4}(15.85-19.71) \mathrm{mg} / \mathrm{l}$ had no significance in both location and time. Polychaete family and species identified in this study include: Eunicidae (Lumbrinereis aciculata, Lumbrinereis californiensis), Syllidae (Syllis ramosa, Syllis gracillis, Syllis armata), Capitellidae (Capitella Capitata), Spionidae, Glyceridae and Nereidae (Nereis diversicolor). The dry season witnessed a high number of polychaetes, about $65 \%$ of the total number of polychaetes collected from all study locations, while the wet season experienced a low count of about $34 \%$ of the total polychaetes collected from all sampled stations. The presence of lumbrinereis sp indicates negatively a poor benthic condition which was present with $25.8 \%$ abundance. The high abundance of Nereis sp with $45 \%$ abundance indicates heavy metals pollution and the presence of Glycera sp with $4 \%$ percentage abundance and Syllid sp with $15.6 \%$ percentage abundance indicates unpolluted conditions. In conclusion the abundance and diversity of polychaetes in Marine base, Abuloma and Kalio Ama were generally poor. This is evident by the poor abundance, composition and diversity of benthic fauna of the study area.

KEYWORDS: Intertidal Polychaetes, Pollution, Anthropogenic Activities, Nigeria 


\section{INTRODUCTION}

The Polychaeta also known as the bristle worms or polychaetes, are a paraphyletic class of annelid worms, generally found in the sediment of the marine and brackish environment and having over 10,000 species (Knox 1977). Because the polychaetes are a major component of the sediment in marine and brackish environments they play an important role in the cycling of nutrients and other chemicals between the sediments and the water column. Polychaetes play important roles in the recycling of nutrients by breaking them down to organic particles to enable other life forms to access them for nutritional purposes. They play a vital part in the food chain as over 100 organisms prey on them; they provide food for fishes and their larvae. So it aids the fishing industry that provides food for humans (Fauchad and Jumars, 1979). However, the aquatic environment has been subjected to a drastic pollution during the last few decades due to industrial, agricultural and sewage effluents and runoffs from major rivers along their coasts (Bat et al., 2018). Sediment is the sink for numerous classes of environmental pollutants in the aquatic environment (Ikem et al. 2003) both organic and inorganic and it harbours macrobenthic epifauna and infauna. The sediment in which the benthic organisms live is continuously modified by the introduction of new chemicals. The vast majority of these benthos are sedentary or very slow moving and therefore, susceptible to a variety of pollutants and disturbances. They are species with different tolerances to stress, they have a high sensitivity and tolerance to different environmental conditions and their ability to quickly respond to environmental changes (Knox, 1977). The intertidal layer is highly susceptible to pollutants from various sources of pollution, it generally contains organisms that adapt to difficult environmental conditions. Polychaetes can be used as indicators of quality of marine environment (Surugiu. 2005). The Bonny Estuary is one of the richest estuaries in the Niger Delta aquatic ecosystem, with a network of creeks/tributaries linking various habitats of highly economic and ecological importance. These ecosystems are often the site where many pollution problems exist (Saiz-Salinas and Gonzalez Oreja, 2000, Ekweozor et al., 2004) and where pollution loading caused significant changes in abundance and species composition. A number of studies have been carried out on the benthic communities of the upper Bonny estuary (Ekweozor, 1996; Umesi and Daka, 2004; Ikomah et al., 2005; Moslen et al., 2006; Daka et al., 2007; Daka and Moslen, 2013; Miebaka and Daka, 2013; Moslen and Daka, 2014; Moslen et al., 2015). This study is aimed at accessing the abundance and distribution of the intertidal polychaetes in these locations, hereby using the polychaetes as indicators of pollution caused by anthropogenic activities.

\section{MATERIALS AND METHOD}

STUDY SITE: Three sampling stations were located along the Okpoka river and Amadi creek (Marine base, Abuloma and Kalio-Ama). Duplicate samples were collected monthly for 6 months beginning from July to December 2020 from the sampling stations. The sampling stations and their geographical coordinates are as follows: Station 1 (N04 ${ }^{0} 46^{\prime} 07.7^{\prime \prime}$, E00 $07^{0} 01^{\prime}$ 49.7') and 2 (N04 46' 10.7', E007 03' 48.9')and 3 (N04 ${ }^{0} 45^{\prime}$ 26.9”, E007 03' 53.5"). All sampling stations were located around the jetties, where boats are being parked and petroleum products are loaded, sewages and domestic waste dumps are being discharged by dwellers of this region. The activities around this region include dredging/sand mining by companies or locals, fishing, navigation by speed boat/vessels, transportation of people and petroleum 
products and recreational activities, parking of large vessels and ships, Boat making by boat making companies.

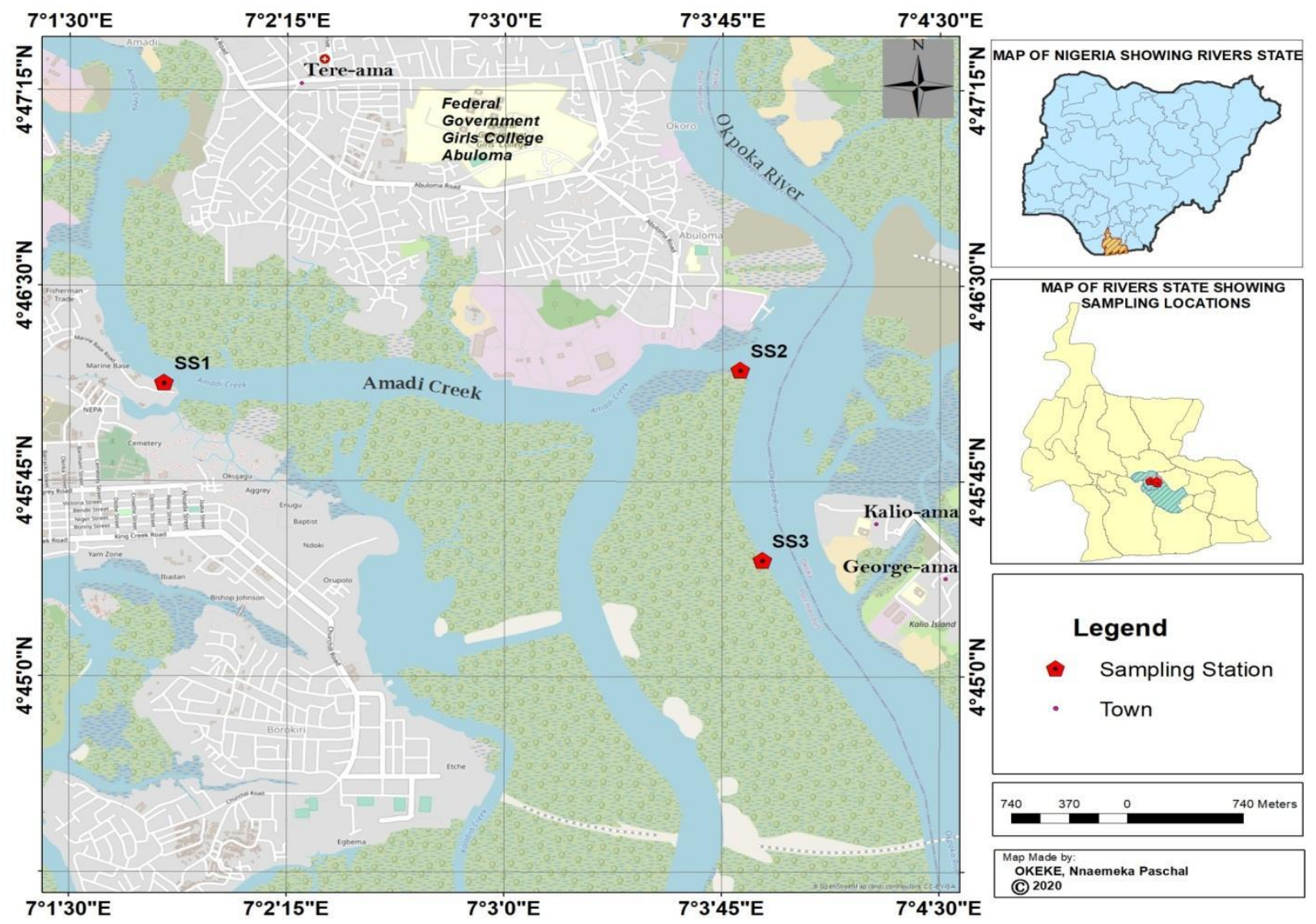

Fig 1: Map of Study area with Sampled Stations

\section{Sample Collection and Analysis}

Water and sediment Samples were collected along the shoreline of the Okpoka river and Amadi creek for 6 months. Insitu readings were carried out on the spot using Hanna HI 9829 Multi parameter Water Quality Checker to check for $\mathrm{pH}$, temperature, salinity, conductivity, TDS and turbidity. Intertidal Sediments were collected with the use of a quadrant of $1 \mathrm{ft}$ by $1 \mathrm{ft}$ ( 24 $\mathrm{cm}^{2}$ ) to a depth of $10 \mathrm{~cm} .10$ grams of the Sediment Samples were wrapped in properly labeled aluminium foils and put in ice coolers and taken to the laboratory for analysis. Sediment samples were dried at room temperature in the laboratory for the analysis of sediment characteristics. For the analysis of biological samples, sediment samples were washed using $0.5 \mathrm{~mm}$ mesh sieve to obtain macro fauna. The materials retained by the sieve were placed in a container and preserved with 5\% formalin as the preservative and 5\% Rosebengal as the stain to facilitate sorting in the laboratory. Laboratory analysis of infauna was carried out shortly after field sampling. Aliquots of the samples were transferred on to a white surgical tray with water for sorting. The detrital sediment samples were then sorted using a pair of forceps and a hand lens. The macro-infanuna found were collected and preserved in small vials containing 
$5 \%$ formlin water mixture. The contents were later identified to the lowest possible taxonomic level using appropriate keys (Day et al., 1989) and others (Fauchald, 1977). Only the heads of organisms were counted, since the individuals were sometimes fragmented.Water samples were collected from the intertidal pools using plastic containers and stored in an iced cooler before being transported to the laboratory. Physico-chemical parameters were analyzed on sediment and water samples. DO, BOD, Nitrate, Phosphate and Total petroleum hydrocarbon (TPH) were analyzed using the standard method as stated in APHA (2012).

Data Analysis: Anova was used to test for significant differences in the physicochemical parameters that was measured across the three stations and the abundance of polychaetes. Tukey test also was used to analyse results using the Minitab software.

\section{RESULTS}

The months of July, August, September represented the wet season, while the months of October, November and December represented the dry season. The result of the physico chemical parameters for the study stations are summarized in Table 1.0. BOD values ranged from 4.0 - 3.3mg/l across stations over the period of study with Marine Base and Kalio-ama having higher $\mathrm{BOD}$ values than Abuloma. BOD values were significant $(\mathrm{P}<0.05)$ across the months of sampling. The mean $\mathrm{NO}_{3}$ levels ranged from $4.1-2.1 \mathrm{mg} / \mathrm{l}$. Wet season had higher values. Abuloma had higher values in $\mathrm{NO}_{3}$ followed by Marine Base and Kalio-Ama with a significant difference between months. The mean $\mathrm{PO}_{4}$ level ranged from 0.8 to $1.1 \mathrm{mg} / \mathrm{l}$ with Abuloma having higher value followed by Kalio-ama and Marine base. There was a Significant difference in location. The mean $\mathrm{SO}_{4}$ levels ranged from $7.5-15.3 \mathrm{mg} / \mathrm{l}$ with significance $(\mathrm{p}<0.05)$ in months. Kalio-Ama has the highest amount of $\mathrm{SO}_{4}$ followed by Marine base and Abuloma with the least. TPH levels ranged from $0.0-0.1 \mathrm{mg} / \mathrm{l}$ showing significance $(\mathrm{p}<0.05)$ in time, with higher values in dry season than in wet season. $\mathrm{pH}, \mathrm{EC}$, TDS and Salinity showed significant differences $(\mathrm{p}<0.05)$ across the time and location with Kalio-ama having higher $\mathrm{pH}$ values followed by Abuloma and Marine base. Turbidity and temperature had no significance $(\mathrm{p}<0.05)$ in both location or time, but had higher values in Abuloma and least values in Marine Base and Kalio-ama respectively. Analysis of physico chemical parameters in the sediment as shown in Table 1.1 showed that $\mathrm{NO}_{3}$ levels in sediment samples from the study locations showed significance $(\mathrm{p}<0.05)$ in location and time, with values ranging from $15.5-26.4 \mathrm{mg} / \mathrm{l}$ with Kalio ama having higher values followed by Abuloma and Marine base. $\mathrm{PO}_{4}, \mathrm{SO}_{4}$, and $\mathrm{TPH}$ had higher values in Marine base followed by Kalio-ama and Abuloma, with PO4 showing significance $(\mathrm{p}<0.05)$ in both location and time, SO4 showing no significant difference $(\mathrm{p}<0.05)$ in location and Time and TPH showing significance $(\mathrm{p}<0.05)$ in location. $\mathrm{NO}_{3}, \mathrm{PO}_{4}, \mathrm{SO}_{4}$ and $\mathrm{TPH}$ had higher concentrations in wet season than in dry season 
Table 1.0 Mean Summary Table Of Physico Chemical Parameters Of Surface Water

$\begin{array}{lrrr} & \text { MARINE BASE } & \text { ABULOMA } & \text { KALIO AMA } \\ \mathrm{BOD}, \mathrm{mg} / \mathrm{l} & 4.0 \pm 0.31 & 3.31 \pm 0.38 & 3.65 \pm 0.12 \\ \mathrm{NO}_{3}, \mathrm{mg} / \mathrm{l} & 2.58 \pm 0.80 & 4.10 \pm 1.03 & 2.11 \pm 0.35 \\ \mathrm{PO}_{4}, \mathrm{mg} / \mathrm{l} & 0.82 \pm 0.11 & 1.10 \pm 0.29 & 1.06 \pm 0.09 \\ \mathrm{SO}_{4}, \mathrm{mg} / \mathrm{l} & 9.17 \pm 4.74 & 7.51 \pm 1.67 & 15.38 \pm 2.15 \\ \mathrm{TPH}, \mathrm{mg} / \mathrm{l} & 0.03 \pm 0.02 & 0.04 \pm 0.06 & 0.13 \pm 0.16 \\ \mathrm{pH} & 6.58 \pm 0.10 & 6.83 \pm 0.27 & 6.86 \pm 0.31 \\ \mathrm{DO} \mathrm{mg} / \mathrm{l} & 6.43 \pm 0.59 & 6.44 \pm 0.53 & 6.40 \pm 0.54 \\ \mathrm{EC} \mathrm{ms} / \mathrm{cm} & 22.69 \pm 1.73 & 24.15 \pm 1.42 & 25.89 \pm 0.83 \\ \mathrm{TDS} \mathrm{ppt} & 11.34 \pm 0.88 & 11.97 \pm 0.59 & 12.96 \pm 0.42 \\ \text { Salinity ppt } & 13.65 \pm 1.19 & 14.50 \pm 0.82 & 15.74 \pm 0.59 \\ \text { Turbidity ntu } & 56.05 \pm 15.62 & 75.11 \pm 13.97 & 45.41 \pm 8.12 \\ \text { Temp }{ }^{\circ} \mathrm{C} & 28.30 \pm 0.45 & 31.82 \pm 5.25 & 29.60 \pm 2.01\end{array}$

Table 1.1 Mean Summary Table Of Physico Chemical Parameters In Sediment

\section{MARINE BASE}

$$
\begin{aligned}
& \mathrm{NO}_{3}, \mathrm{mg} / \mathrm{kg} \\
& \mathrm{PO}_{4}, \mathrm{mg} / \mathrm{kg} \\
& \mathrm{SO}_{4}, \mathrm{mg} / \mathrm{kg} \\
& \mathrm{TPH}, \mathrm{mg} / \mathrm{kg}
\end{aligned}
$$

$$
\begin{aligned}
& 15.50 \pm 2.21 \\
& 15.90 \pm 1.77 \\
& 19.71 \pm 4.10 \\
& 34.71 \pm 8.16
\end{aligned}
$$

ABULOMA

$21.52 \pm 3.42$

$13.32 \pm 2.76$

$15.85 \pm 2.67$

$21.93 \pm 8.20$
KALIO AMA

$26.40 \pm 7.99$

$13.59 \pm 0.99$

$18.41 \pm 1.18$

$23.39 \pm 6.36$

A total of 833 polychaetes were collected from sampled locations (Marine Base, Abuloma, and Kalio-ama). The dominant polycheate families are: Eunicidea (Lumbrinereis aciculata, Lumbrinereis californiensis), syllidea (Syllis ramosa, Syllis gracillis, Syllis armata), Capitellidae (Capitella capitata), Spionidae, Glyceridae and Nereidae (Nereis diversicolor). A total number of 354 polychaetes were collected from Marine base which constituted 43\% of all polychaetes, 241 from Abuloma which was 29\%, and 228 from Kalio-ama which was $27 \%$ as shown in Fig 1.1. The dry season witnessed a high number of polychaetes collection of 539 making up about $66 \%$ of the total number of polychaetes collected from all study locations, the highest counts of polychaetes during the dry season was from Marine base with $259(31 \%)$ followed by Abuloma $149(18 \%)$ and Kalio-ama $131(15 \%)$. The wet season experienced a low count of 284 polychaetes which is about $34 \%$ of the total polychaetes collected from all sampled stations. The highest counts of polychaetes in this season was from Kalio-ama with $97(11.6 \%)$ followed by Marine base with $95(11.3 \%)$ and the least was Abuloma with $92(11.1 \%)$ this is shown in fig 1.2 and 1.3. Out of the total number of 
polychaetes species collected from the sampled locations Capitella capitata constituted $2.8 \%$, Lumbrineris aciculata 13.8\%, Lumbrineris californiensis $12 \%$, Nereis diversicolor $34 \%$, Nereis sp 11\%, Spionidae 6\%, Syllis gracilis 2.9\%, Syllis ramosa 3.7\%, Syllis armata 9\%, and Glycera sp 4\% (Table 1.2). Out of the total number of polychaetes collected during the dry season the families Capitellidae constituted $<1 \%$, Eunicidae 18\%, Nereidae 28\%, Spionidae $5 \%$, Syllidea $10 \%$ and Glyceridae 3\%. While in the wet season Capitellidae constituted 3\%, Eunicidae 7\%, Nereidea 17\%, Spionidae 1\%, Syllidea $4.6 \%$ and Glyceridae 1\%. During the dry season Nereis sp had the highest abundance at 2 locations, Marine base 121 and Kalio ama 100, and Eunice $s p$ followed closely with 94 polychaetes at marine base Syllid sp followed closely with 67 polychaetes at Abuloma. During the wet season Nereis sp had the highest abundance at Kalio ama (76) and Marine base (53) which was followed closely by Syllid $s p$ at Abuloma and Eunice sp at the same location. Other polychaetes found in this study had lower abundance but some had significant correlation with the nutrient parameters (Table 1.2) Nereis $s p$ had no significance with any of the parameters but was more abundant. Lumbrinereis $s p$ had a negative significance with $\mathrm{NO}_{3}$ but had a positive significance with $\mathrm{PO}_{4}, \mathrm{SO}_{4}$ and $\mathrm{Tph}$. Capitellidae $s p$ had a negative significance with $\mathrm{NO}_{3}$ and $\mathrm{Tph}$ but had a positive significance with Phosphate and Sulphate. Spionidae sp had a negative significance with all parameters tested. Glycerides $s p$ had a negative significance with all parameters and Syllidea sp had a negative significance with all parameters tested.

Table 1.2: Monthly Summary of Specie Abundance of Polychaetes Identified in the Intertidal Sediment of the Okpoka River (July 2020 - December 2020)

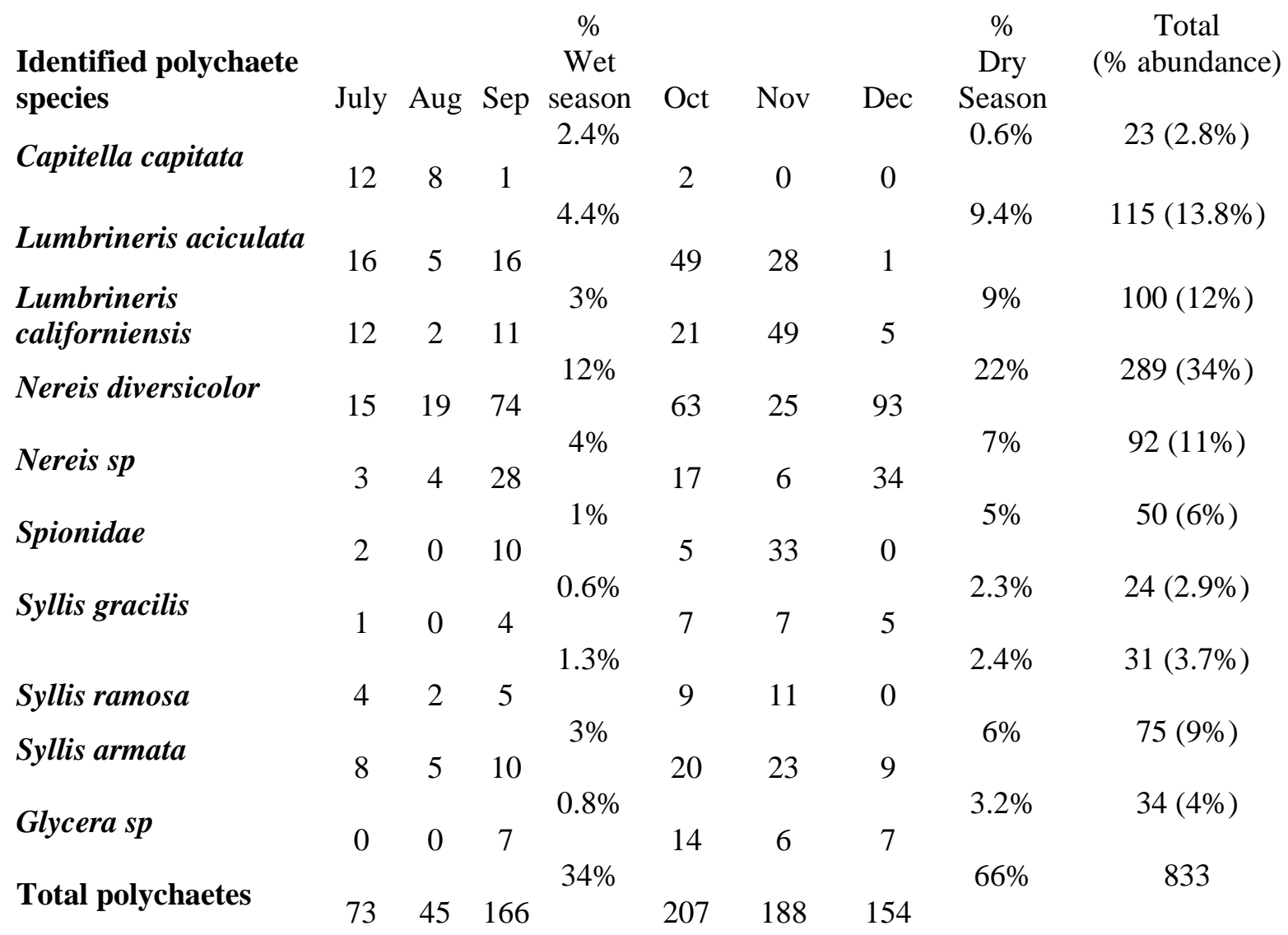


Table 1.2 Correlation between Sediment Chemistry And Polycheates

\begin{tabular}{lrrrr} 
Phosphate & \multicolumn{1}{c}{$\begin{array}{c}\text { Nitrate } \\
\text { Sulphate }\end{array}$} & \multicolumn{1}{c}{ Phosphate } & \multicolumn{1}{l}{ Sulphate } & \multicolumn{1}{l}{ TPH } \\
TPH & -0.81013 & 1 & & \\
Syllid sp & -0.845404 & 0.33014 & 1 & \\
Nereis sp & 0.143687 & 0.813527 & 0.555356 & -0.31453 \\
Lumbrineris sp & -0.09877 & -0.69168 & -0.12881 & 0.11665 \\
& -0.79649 & 0.776914 & 0.376943 & 0.680962 \\
Capitellidae & -0.72375 & 0.749673 & 0.635035 & 0.593869 \\
Spionidae & -0.40296 & 0.255986 & -0.20687 & 0.547633 \\
Glyceridae & -0.0722 & -0.47486 & 0.13924 & 0.055152
\end{tabular}

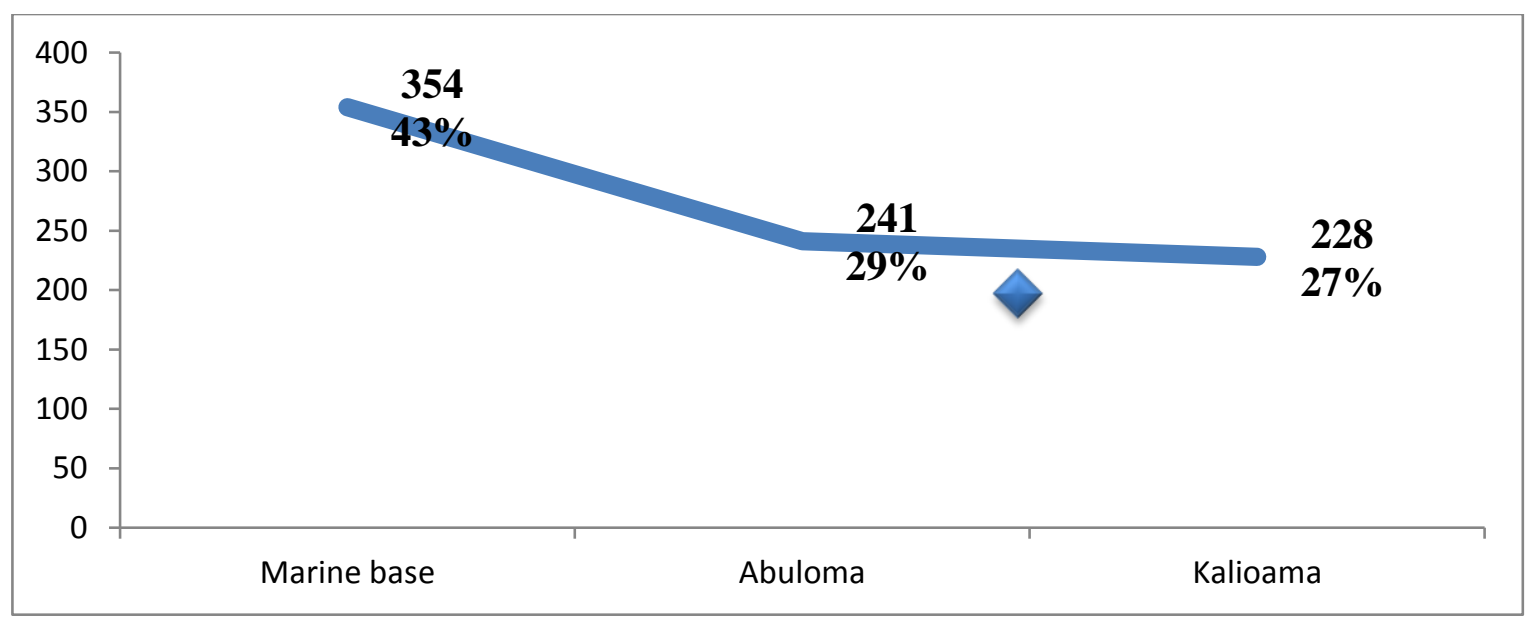

Fig 1.1: Distribution Abundance Of Polychaete Across Sampled Locations

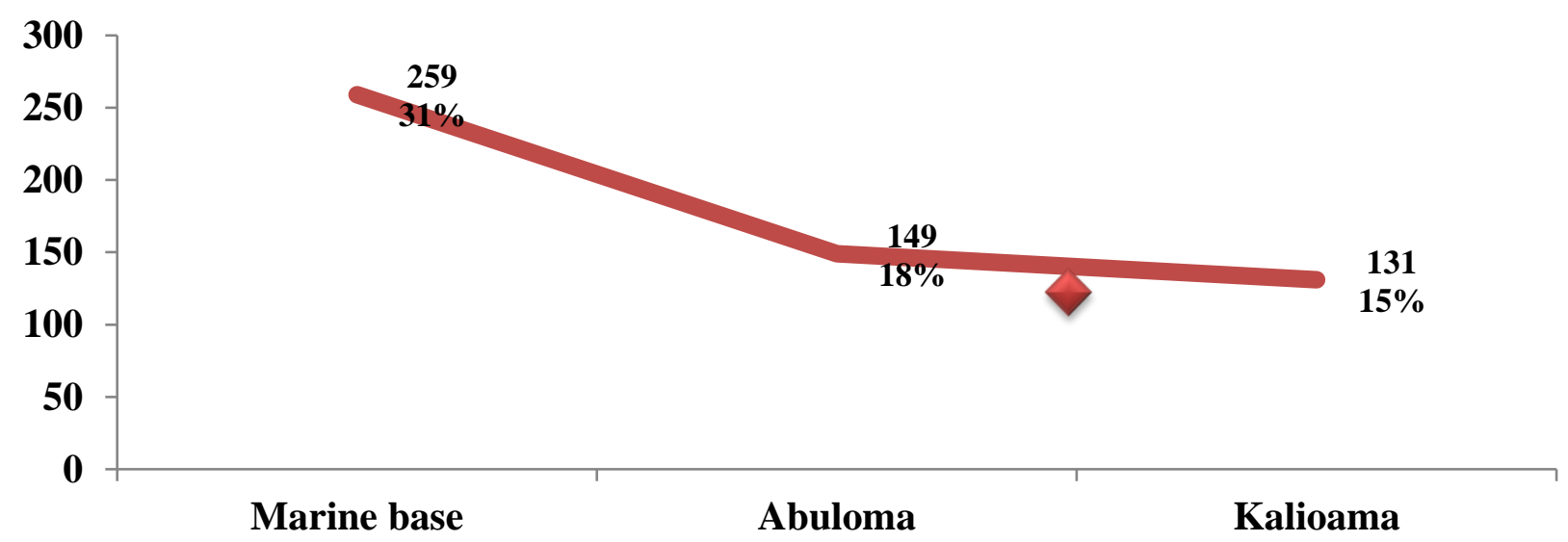

Fig 1.2: Seasonal Abundance Across Sampled Stations (Dry) 


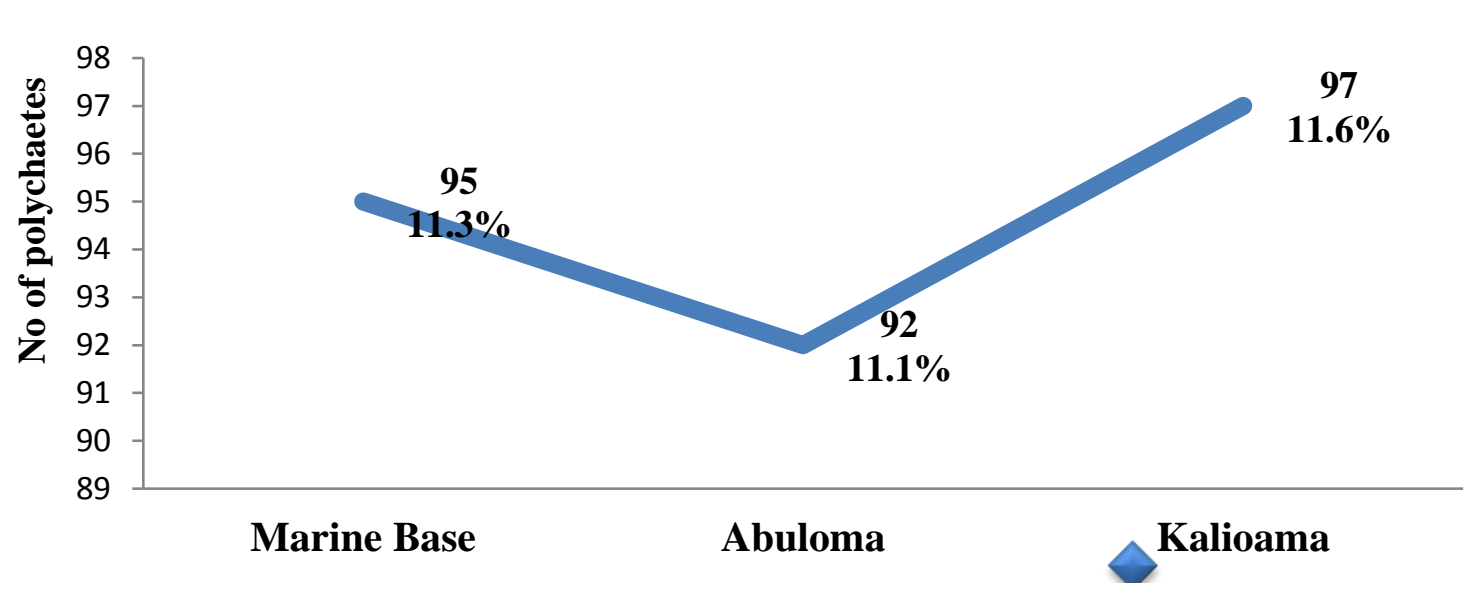

Fig 1.3: Seasonal Abundance Across Sampled Stations (Wet)

\section{DISCUSSION}

All analysis carried on water where within the permissible limits of $\mathrm{WHO}$ except $\mathrm{PO}_{4}$, turbidity and temperature. $\mathrm{PO}_{4}$ had higher concentrations generally which may be as a result of sewage, run offs or industrial effluent discharge in the river which causes organic enrichment in these waters. This result was higher than the results of Oluwayesimi et al., (2016) who analyzed and compared the river waters in Port harcourt based on their physico chemical and microbial properties and $\mathrm{PO}_{4}$ had values in the Okpoka river ranging from $0.188-0.28 \mathrm{mg} / \mathrm{l}$. Turbidity also had high values ranging from $45.41-75.11 \mathrm{NTU}$ which is higher than the WHO permissible limits. This can be as a result of dredging activities, nutrient enrichment (as a result of high $\mathrm{PO}_{4}$ that eventually leads to eutrophication), navigation by speed boats or large vessels. The works of Oluwayesimi et al., (2016) also stated that Okpoka river had the highest turbidity values ranging from 36.0 - 52.7NTU in comparison with other rivers worked on in Port harcourt. Temperature had slightly high values in abuloma $(31.82 \pm 5.25)^{\circ} \mathrm{C}$ as compared to the WHO limits. TPH had values ranging from $0.03-0.13 \mathrm{mg} / \mathrm{l}$ which was low as compared to the work done by Moslen and Aigberua (2018) on heavy metals and hydrocarbon contamination of surface water at azuabie creek within the bonny estuary which values ranged from 0.07 $45.20 \mathrm{mg} / \mathrm{l}$.

The nutrient parameters analysed on the sediment samples showed that $\mathrm{NO}_{3}$ had high values ranging from $14.04-26.50 \mathrm{mg} / \mathrm{kg}$ as compared to the work done by Wokoma and Friday (2017) on the sediment physico chemical characteristics in Sombreiro river River state, $\mathrm{NO}_{3}$ values ranged from $1.34-4.0 \mathrm{mg} / \mathrm{kg}$ which was lower than the values gotten. An investigation done by Umesi and Daka (2004) showed that $\mathrm{NO}_{3}$ values ranged from $0.97-6.47 \mathrm{mg} / \mathrm{kg}$. Also the results of $\mathrm{PO}_{4}$ ranged from $13.32-15.90 \mathrm{mg} / \mathrm{kg}$ which was higher than the findings of Wokoma and Friday (2017) whose values ranged from $0.39-2.97 \mathrm{mg} / \mathrm{kg}$ and the findings of Obunwo et al., (2004). Sulphate showed results ranging from $15.85-19.71 \mathrm{mg} / \mathrm{kg}$ in the sediments which was high as compared to the work done by Ogamba et al., (2005). The high sulphate values are attributed to the strong influence of the sea water characterized by its High sulphate concentration (RPI. 1985). In addition, sulphate from effluent sources (leachates from dump sites and municipal runoffs) may possibly also contribute to the high concentrations observed. Tph had results ranging from $21.93-34.71 \mathrm{mg} / \mathrm{kg}$ which was within the DPR permissible limits 
as compared to the results gotten from Chioma and Chioma (2014) that reported a high amount of TPH in the sediment of Bodo, Ogoni Land which ranged from $1007-1104 \mathrm{mg} / \mathrm{kg}$.

The result of the abundance and distribution of the Polychaetes have shown that the dominant polychaete families in this study area are Capitellidae, Glyceridae, Nereidae, Eunicidae, Spionidae and Syllidae. In comparison with the studies of George et al., (2009) showed that a total of 19 species of polychaete was identified with Nereis sp being the most dominant in Okpoka river of the Bonny estuary. Work done by Anaero-Nweke (2013) who discovered that 6 Nereis species were dominant in the study area. Several other studies have observed negative effect of effluent discharge on the abundance and diversity of benthic community in the niger delta (Ekweozor, 1996; Umesi and Daka, 2004;Ikomah et al., 2005; Wake, 2005; Dean, 2008; Moslen and Daka, 2014). The observed differences in time and location may be attributed to the different anthropogenic activities and environmental differences particular to each area along the creek. Polychaete specie Capitella capitata showed lowest abundance both in dry season and wet season in contrast with Work done by Ajao and Fagade (1990), reported that Capitella capitata and Nereis $s p$ were found associated with sites grossly polluted with organic matter, heavy metals and petroleum hydrocarbon and in conformity with the research done by Dean (2008) who stated that Capitella capitata species are more dominant in high organic situations associated with aquaculture facilities and sewage which is often a mixture of high organic materials. Also at one time the Capitella capitata was once believed to be indicators of environmental degradation. The works of Dean (2008) found out that Capitella. capitata were highly dominant at the most polluted site and were therefore designated as indicators of polluted conditions. The Eunice sp showed the second highest abundance both in dry and wet season. The Eunice $s p$ have been used as negative indicators of poor benthic conditions, that is, their absence in a community is an indication of poor environmental condition (Olsgard et al., 2003). Nereis $s p$ have been said to be indicators of highly polluted environments with heavy metals such as Cd, and Hg. Work done by Dean (2008) noted that the family Nereididae were found to be very sensitive to $\mathrm{Hg}$ while the more $\mathrm{Hg}$ tolerant specie was found to be the Nereis diversicolor and work done by King et al., (2004) noticed that the family Nereididae are sensitive to a very high amount of heavy metal but aren't sensitive to a low amount of heavy metals. Syllid $s p$ had only $15 \%$ of the total abundance of polychaetes gotten from the study location. Mendez et al., (1998) indicated that the Syllid $s p$ were considered tolerant of pollution and not indicators species. Glycera sp had only $4 \%$ of the total polychaetes obtained from the study location and work done by Pearson (1975) and Rosenberg (1976) indicated that glycerides species are characterized as indicators of unpolluted conditions.

\section{CONCLUSION}

The presence or absence of polychaete in Marine base, Abuloma and Kalio ama gives an indication of the possible pollutant present. This is evident by the abundance, composition and diversity of polychaetes present in the study area. . The presence of Capitella capitata indicates organic matter and petroleum hydrocarbon pollution which was the least present with $2.8 \%$ percentage abundance. The presence of lumbrinereis $s p$ indicates negatively a poor benthic condition which was present with $25.8 \%$ abundance. The high abundance of Nereis $s p$ with $45 \%$ abundance indicates heavy metals pollution and the presence of Glycera sp with $4 \%$ percentage abundance and Syllid sp $15.6 \%$ percentage abundance indicates unpolluted conditions. The findings of this result has given us a hint on the possible pollutant discharged 
into the aquatic system as a result of anthropogenic activities. The discharge of pollutants into this creek should be discouraged and awareness should be given to the dwellers of this region of the possible side effects these pollutants discharged could cause to this aquatic environment.

\section{REFERENCES}

Ajao, E. A. and Fagade, S. O. (1989). A study of sediment and communities in Lagos lagoon, Nigeria. Oil and Chem. Pollut., (7):85 - 117.

Anaero-Nweke,G. N. (2013).Impact of oil refinery effluent on the water quality: case study of Ekerikana creek in Nigeria. A Thesis Submitted to the Department of Environmental Science of the Kwame Nkrumah University of Science and Technology, Ghana.

Chioma B. C., Chioma B. E. (2014) culture dependent characterization of hydrocarbon utilizing bacteria in selected crude oil impacted sites in bodo, ogoni land, nigeria. African journal of environmental science and technology 2014; 8(6): 401-406

Daka, E.R. and Moslen, M. (2013). Spatial and temporal variation of physicochemical parameters of sediment from Azuabie creek of the upper Bonny estuary, Niger Delta. Research Journal of Environmental and Earth Sciences, 5(4), 291-228

Daka, E.R., M. Moslen, C.A. Ekeh and I.K.E. Ekweozor, 2007. Sediment quality status of two creeks in the upper Bonny estuary, Niger Delta, in relation to urban industrial activities. Bull. Environ. Contam. Toxicol., 78, 151-521.

Day, Jr. J.W., C.A.S. Hall, W.M. Kemp and A. YanezArancibia,1989. Estuarine Ecology. John Wiley and Sons, New York, pp: 554-558

Dean, H.K. (2008). The use of polychaetes (Annelida) as indicator species of marine pollution. Rev. Biol. Trop. (Int. J. Trop. Biol., 56(4), 11-38.

Ekweozor, I. K. E, Daka, E. R, Ebere, Bob-Manuel, K. N. O., (2004). An estuary under stress: The case study of 18 years chronic hydrocarbon pollution of Bonny Estuary, Nigeria.. Journal of Nigerian Environmental Society, 2(1),12-15.

Ekweozor, I.K.E. (1996). The Impact of Chronic discharges of petroleum hydrocarbons on the littoral macrofauna of Elechi Creek, Nigeria. Niger Delta Biologia, 1(1),55-66.

Fauchald, K. and P.A. Jumars, 1979. The diet of worms: A study of polychaete feeding guilds. Oceanogr. Mar. Biol. Annu. Rev., 17: 193-284.

George ADI, Abowei JFN, Daka ER. Benthic macro invertebrate fauna and physico-chemical parameters in Okpoka Creek sediments, Niger Delta. Nigeria International Journal of Animal and Veterinary Advances. 2009;1(2):59-65.

George, A.D.I., Abowei J.F.N., and Alfred-Ockiya J.F. (2010).The Distribution, Abundance and Seasonality of Benthic Macro Invertebrate in Okpoka Creek Sediments, Niger Delta, Nigeria. Research Journal of Applied Sciences Engineering and Technology, 2(1), 11-18

Ikem A, Egiebor NO, Nyavor K (2003)) Trace elements in water, fish and sediment from Tuskegee Lake, Southeastern USA. Water Air Soil Pollut 149:51-75)

Ikoma, F. B. , Ekweozor, I. K. E., Daka, E. R. and Dambo, W. B. (2005). The impact of fertilizer plant effluents on the littoral benthos of an estuarine creek in the Niger Delta, Nigeria. African journal of Environmental Pollution and Health, 4(2), $62-71$.

King, C.K., M.C. Dowse, S.L. Simpson \& D.F. Jolley. 2004. An assessment of five Australian polychaetes and bivalves for use in whole-sediment toxicity tests: toxicity and accumulation of copper and zinc from water and sediment. Arch. Environ. Con. Tox. 47:314-323. 
Knox GA. The role of polychaetes in benthic soft-bottom communities. Essays on polychaetous annelids in memory of Dr. Olga Hartman. 1977;547-604.

Méndez, N. \& F. Páez-Osuna. 1998. Trace metals in two populations of the fireworm Eurythoe complanata from Mazatlán Bay: effect of body size on concentrations. Environ. Pollut. 102: 279-285.

Miebaka, C. A. and Daka, E. R. (2013). Dynamics of Zooplankton of Azuabie Creek in the Upper Bonny Estuary of the Niger Delta. International Journal of Fisheries and Aquatic Sciences, 2(2), 29-37.

Moslen M., Aigberua A. (2018) Heavy metal and Hydrocarbon contamination of surface water in Azuabie creek within Bonny estuary, Nigeria. J.Appl. Sci. Environ. Manage. 2018; 22(7)1083-1088

Moslen, M. and Daka E.R. (2014). Attributes of the subtidal macrobenthos of Azuabie Creek in the upper Bonny Estuary, Niger Delta, Nigeria. Res. J. Environ. Earth Sci., 6, 143155.

Moslen, M., Daka, E.R., Ekeh, C.A. and Ekweozor, I.K.E. (2006). Physicochemical properties of two estuarine creeks in the Niger Delta in relation to urban/industrial activities. Niger Delta Biologia, 5(2), 115-122.

Moslen, M., Miebaka, C. A. and Daka, E. R. (2015). The Menace of solid wastes in some creeks around Port Harcourt: The way forward. Journal of Nigerian Environmental Society, 9(1), 86-91

Obunwo, C. C., S. A. Braide, W. A. 1. Izonfuo, A.C Chindah (2004) Influence of urban activities on the water quality of a fresh water stream in the Niger Delta, Nigeria. Journal of Nigeria Environmental Society 2004; 2(2): 196-209.

Ogamba EN, Chindah AC, Ekweozor IKE, Daka ER, Onwuteaka J and Bawo DDS (2005) Impact of human activities on the plankton communities of the Elechi creek complex in the Niger Delta, Nigeria. Niger Delta Biologia 5:1-9

Olsgard F Brattegard T and Holthe T (2003) Polychaetes as surrogates for marine biodiversity: lower taxonomic resolution and indicator groups. Biodiversity and Conservation. 12, 1033-1049.

Oluwayemisi et al., (2018) comparative studies of some river waters in port harcourt based on their physico chemical and microbiological analysis, niger delta region of nigeria. International journal of basic and applied science 2015;3(3)29-37

Pearson, T.H. 1975. The benthic ecology of Loch Linne and Loch Eli, a sea-Loch system on the west coast of Scotland. IV. Changes in the benthic fauna attributable to organic enrichment. J. Exp. Mar. Biol. Ecol. 20: 1-41.

Research planning institute (RPI) (1985) Environmental baseline studies for the establishment of control criteria and standards against petroleum related pollution in Nigeria. Research Planning Institute, Colombia, South Carolina, U.S.A. RPI/R/84/4/1517.

Rosenberg, R. 1976. Benthic faunal dynamics during succession following pollution abatement in a Swedish estuary. Oikos 27: 414-427

Saiz-Salinas, J. I. and Gonzalez-Oreja, J. A. (2000). Stress in estuarine communities: lessons from the highly-impacted Bilbao Estuary (Spain). J. Aqua. Ecos. Stress and Recovery., $7,43-55$.

Surugiu V. (2005). The use of polychaetes as indicators of eutrophication and organic enrichment of coastal waters: a study case - Romanian Black Sea Coast. Analele științifice ale universitatii “Al.I. Cuza”Iasi, s. Biologie animala, LI 
Umesi, N. and Daka E. R. (2004).Effects of abattoir run-off on benthic populations in a tidal creek in the upper Bonny estuary. Journal of Environmental Management and Education, 1(2), 158-170.

Wake, H., (2005). Oil refineries: a review of their ecological impacts on the aquatic environment. Estuar. Coast Shelf Sci., 62, 13-140.

WHO, (2006). Guideline for drinking water quality (electronic source). Incorporating first addendum, 3rd edn, volume 1. Recommendations. World health Organization, Geneva.

Wokoma O.A.F., Upadhi F. (2017). The sediment physicochemical characteristics in Sombreiro Rivers state, Nigeria. International journal of innovation 2017;7(3):16-21. 